\title{
A CUTÍCULA DOS ESTERNITOS EM ISÓPODOS TERRESTRES: MUDANÇAS NA CONDIÇÃO OVÍGERA
}

\author{
Horch, A.P. ${ }^{1, *}$; Wood, C.T. ${ }^{1}$ \& Araujo, P.B. ${ }^{1}$ \\ ${ }^{1}$ Universidade Federal do Rio Grande do Sul (UFRGS), Campos do Vale, Laboratório de Carcinologia. \\ *Autor correspondente: amandahorch@gmail.com
}

As fêmeas da subordem Oniscidea possuem uma bolsa incubadora ventral, delimitada pelos esternitos e oostegitos, chamada de marsúpio. Dois tipos de marsúpios são conhecidos na subordem: o tipo anfíbio e o tipo terrestre. O tipo anfíbio, presente em espécies da linhagem Synocheta, é aberto e conectado ao sistema condutor de água. O tipo terrestre, presente em Crinocheta, é fechado e possui cotilédones. O papel dos esternitos durante o período gestacional nunca foi devidamente investigado. Neste estudo, buscou-se verificar se há diferença na espessura dos esternitos entre fêmeas nas duas condições, ovígeras e não ovígeras, de duas linhagens. Três fêmeas ovígeras e três não ovígeras das espécies Atlantoscia floridana (Van Name, 1940) (Crinocheta) e Styloniscus spinosus (Patience, 1907) (Synocheta) foram fixadas em Karnovsky e infiltradas em parafina para histologia. Cortes parassagitais foram corados com hematoxilina-eosina de Harris e fotografados em microscópio óptico. A espessura da cutícula de um esternito envolvido no marsúpio foi medida 10 vezes em cada um dos 5 cortes selecionados de cada indivíduo. As duas condições foram comparadas utilizando modelos lineares. Em A. floridana, a cutícula do esternito é significativamente mais fina nas fêmeas ovígeras $(\sim 1,93 \mu \mathrm{m})$ quando comparadas às não ovígeras $(\sim 1,14 \mu \mathrm{m})$. Também foi encontrada uma diferença na espessura da cutícula do esternito nas fêmeas de $S$. spinosus, sendo esta relacionada à variação das medidas individuais e à condição. Um mesmo indivíduo apresenta porções finas e porções espessas na cutícula. Ainda assim, as fêmeas ovígeras $(\sim 0,91 \mu \mathrm{m})$ possuem uma cutícula do esternito significativamente mais fina (não ovígeras aprox. 0,96 $\mu \mathrm{m})$. Porém, como o marsúpio é aberto nessa espécie, é provável que o sistema condutor de água ainda seja o principal responsável pela nutrição e oxigenação dos ovos em desenvolvimento. O marsúpio da linhagem Synocheta é pouco conhecido e nunca havia sido estudado em Styloniscus. Ambas as espécies analisadas no presente trabalho apresentaram diferenças na espessura da cutícula dos esternitos quando no período ovígero, indicando que estes possam participar da nutrição e da oxigenação da prole durante a gestação. Desta forma, estudos futuros são importantes para averiguar se essa diferença está intimamente relacionada com a passagem de substâncias para a prole.

Palavras-chave: cutícula, fêmeas ovígeras, microscopia óptica, tatuzinhos, isopoda. 